Abstracta Iranica Abstracta Iranica

Revue bibliographique pour le domaine irano-aryen

Volume 22 | 2001

Comptes rendus des publications de 1999

\title{
Barkamol avlod orzusi. Tachkent, Šarq narrijot- matbaa konserni, 1999, 183 p. [Pour un enfant parfait]
}

\section{Bayram Balci}

\section{(2) OpenEdition}

1 Journals

Édition électronique

URL : http://journals.openedition.org/abstractairanica/37271

DOI : 10.4000/abstractairanica.37271

ISSN : 1961-960X

Éditeur :

CNRS (UMR 7528 Mondes iraniens et indiens), Éditions de l'IFRI

\section{Édition imprimée}

Date de publication : 15 mai 2001

ISSN : 0240-8910

Référence électronique

Bayram Balci, « Barkamol avlod orzusi. Tachkent, Šarq na·rijot-matbaa konserni, 1999, 183 p. [Pour un enfant parfait] », Abstracta Iranica [En ligne], Volume 22 | 2001, document 613, mis en ligne le 17 février 2010, consulté le 11 octobre 2020. URL : http://journals.openedition.org/abstractairanica/37271 ; DOI : https://doi.org/10.4000/abstractairanica.37271

Ce document a été généré automatiquement le 11 octobre 2020

Tous droits réservés 


\title{
Barkamol avlod orzusi. Tachkent, Šarq na.rijot-matbaa konserni, 1999, 183 p. [Pour un enfant parfait]
}

\author{
Bayram Balci
}

Cet ouvrage est un recueil de discours et d'articles attribués au président ouzbek Islom Karimov, qui y livre sa conception des réformes à entreprendre en matière d'éducation et de formation des élites et des cadres du pays. Au-delà du barrage de la langue de bois, s'esquissent les priorités présidentielles pour la société ouzbèke du futur. Parmi celles-ci, viennent en première place la réforme du système scolaire, la formation de nouveaux cadres et enseignants, et la participation des pédagogues à la construction d'une « pensée nationale ouzbèke ». Désignée par le président sous le terme de mafkura, celle-ci est souvent évoquée, mais jamais vraiment explicitée 鬼 si ce n'est comme nécessité de former de jeunes générations dévouées à leur pays et pourvues d'une morale (adab) conforme à l'esprit national ouzbek. Il faut peut-être noter que ce livre a fait l'objet d'une traduction en turc grâce à la société Silm, qui gère les lycées nurcu en Ouzbékistan. Probablement coûteuse, eu égard à la qualité inhabituelle du papier et du brochage, cette édition révèle l'ambition de la direction générale des lycées turcs, à la recherche constante d'une reconnaissance institutionnelle par le régime karimovien.

INDEX

Thèmes : 13.3. Asie centrale 
AUTEURS

BAYRAM BALCI

Paris 